\title{
Effect of gluten-free flour on physical properties and quality characteristics of biscuits
}

\author{
Jehan, B. Ali* ; AND M. F. Abol-Ela \\ Regional Center for Food and Feed, Agriculture Research Central, Ministry of Agriculture, \\ Egypt. \\ Corresponding author: Email; alijehan555@yahoo.com
}

\begin{abstract}
Celiac disease is an autoimmune disorder characterized by intolerance to gluten. So, the aim of this study is to produce gluten-free biscuits for individuals with gluten allergy. Biscuits of rice flour, corn, sorghum and the mixture were prepared with mix 1 rice and corn (1: 1), mix2rice and sorghum (1:1) and mix 3 rice, corn and sorghum (1:1:1). Chemical composition of flour samples moisture; protein, fat, ashand fiber were measured under this study. In the prepared biscuit samples, physical properties (length, width, thickness, weight, volume and specific ratio), color characteristics and sensory properties were measured. Wheat flour recorded the highest value of protein (12.9\%) follow up Sorghum flour recorded (10.8\%). Sorghum flour was the high level fiber $(6.50 \%)$ in all flour. Protein sedimentation $(22.0 \%)$ was high in sorghum flour then mixtures (mix 1, mix 2 and mix 3 ) were recorded 20, 21, and $19 \%$ of gluten free flour but wheat flour $(33.0 \%)$. Wheat flour was the lowest value of falling number $(401 \mathrm{sec})$ this result was highest Alfa amylase enzyme and prefers of baking then mix 3 (434 sec)but highest falling number was the lowest in Alfa amylase enzyme corn flour $(634 \mathrm{sec})$. Highest water absorption $(57.0 \%)$ was observed in wheat flour followed by rice flour $(54.4 \%)$ while mixturesfree gluten flour had the lowest water absorption $(45.70 \%, 45.70 \%$ and $45.90 \%)$ mix 1 , mix 2, and mix 3 respectively. Corn biscuit recorded the high in whiteness (37.80\%) then wheat flour $(33.66 \%)$ and lowest value was mix 3(23.46 \%). The mix 3 biscuit was high physical properties and over all acceptability for the panel test after wheat biscuit.
\end{abstract}

Key words: Rice flour, corn flour, sorghum flour and mixtures, gluten free biscuits, physicochemical properties, sensory properties, parameter of biscuits.

\section{INTRODUCTION}

Celiac disease or gluten sensitivity is entropathy is a chronic disease of the small intestine caused by exposure to gluten in genetically predisposed individuals Laurineet al., (2002). The main agents responsible for celiac disease are gluten proteins from wheat and similar proteins in other closely related cereals such as barley, rye and oats (Kasarda, 2001).It is a continuous intolerance of gluten, gliadin and responsive prolamins that are present in wheat, rye and barley. When people with celiac disease eat foods containing gluten, their immune system responds by destroying the intestinal villi leading to the malabsorption of nutrients, thus adversely affecting all systems of the body (Hill, et al., 2005). The major characteristics of the disease are intestinal damage due to an immune defect (autoimmune disease) that occurs in people with a genetic background (Amin et al., 2002). This malfunction can appear at any age, but the classical symptoms are most frequently observed during infancy and early childhood, when foods containing gluten are introduced into the diet. Sometimes the disease develops during adolescence or adulthood (usually at age 30-40 years). Preliminary results based on seroepidemiologic studies suggest that 
each recognized case of celiac disease is accompanied by three to seven undetected cases (Rewers, 2005). Varieties of glutenfree productshave to be extended for coeliac patients to allow them tokeep a balanced diet. One possibility is to replace wheat flourin products by gluten-free ingredients, like e.g. corn and potato starch in tulumba dessert (Yildiz and Bulut, 2017) orrice in white bread (Lopez et al., 2004).

Gluten-free bakery products that are prepared with gluten-free flours often tend to have reduced quantities of fiber, proteins, iron and B vitamins compared with wheat products (Matos and Rosell, 2011). Therefore, a re-design of the gluten-free bakery goods is needed for obtaining products with similar nutritional composition to that of their gluten counterparts. Rice is the main staple food for many countries, providing $20 \%$ of the food energy supply in the world. It is known as queen among cereals after wheat.

Rice is characterized by low prolamin, hypoallergenic activity, insipid taste, low sodium and high digestible carbohydrate contents, which is suitable to be incorporated into celiac diets (Phimolsiripol, et al., 2012).

Rice flour has been utilized to prepare gluten-free bakery products, such as bread and cake, which are traditionally made with wheat flour. Rice is naturally glutenfree and contains proteins that are known to be nutritious and hypoallergenic (Helm and Burks, 1996).

Acorns, the fruit of oak trees, have been an important part of traditional dietsof people throughout the world and are reported to have potentialhealth benefits (PolimacandLukinac, 2015). Acorn flour isdesirable from a nutritional point of view, because of the content of fat (of which over $80 \%$ is unsaturated), proteins, and considerable amountof electrolytes (calcium, magnesium, potassium, and phosphorus), butlittle or no sodium, and is rich in iron, copper, and zinc.Acorn mealcould be a nutritionally functional ingredient in foods that use wheatflour such as cookies, muffins, breads, noodles, pastries, and desertswith a growing presence in the food industry to improve the eatinghabits of individual clients and the general population for health benefitsand disease prevention (Polimac\&Komlenic, 2015).

Maize is a major source of starch and gluten-free. Sorghum (sorghum bicolor) is a gluten-free grain with high potential in the gluten- free food processing. It is the $5^{\text {th }}$ largest crop produced worldwide and has been shown to be safe for celiac disease people (Ciacciet al., 2007). Gluten makes them expand during baking, and helps to retain moisture for some time (He and Hoseney, 1990; Rasmussen and Hansen, 2001). Lack of gluten lead to changes of the shape, texture, smell and taste in bakery, as well as in quick drying of the crumb (Gambuset al., 2001; Gallagher et al., 2003a;Lazaridouet al., 2007).

The preparation of gluten-free bakery products requires application of different flours in exchange for wheat flour, so the resulting taste very often does not resemble that of classical, gluten products. The role of food technologists is to design such as for gluten-free products, which would improve their expansion, structure and taste (Gambuset al., 2001; Gallagher $\boldsymbol{e t}$ al., 2003b, 2004), and would help the people with celiac disease to fulfill the nutritional directions, which imply everyday consumption of dietary fiber, minerals and other food constituents (Thompson, 2000; Case, 2005).

Gluten-free products are usually protein-free products. Removal of proteins deprives the raw material of minerals and vitamins, which negatively impacts its nutritional value. This is the reason why gluten-free products should be supplemented by raw materials naturally free of gluten, and rich in additional nutrients (Korus et al. 2006, Kiskiniet al., 2007).

The dough made of gluten free products is difficult to shape, which is the main technological problem in the 
production of confectionary products (Gambuset al., 2001; Gallagher et al., 2004; Lazaridouet al., 2007). The final recipe must take into account both nutritional and technological issues.

Biscuits are a popular foodstuff consumed by a wide range of population due to their varied taste, long shelf life and relatively low cost. Gluten is known as "heart and soul" of bakery for providing the processing qualities familiar to both the home baker as well as the commercial food manufacturer (Lubnaand Bashir, 2012). Since gluten plays a limited role in defining the process ability and end product quality of biscuits, it can be complemented through some alternate flours in various combinations (Rai, , 2011).

Gluten-free biscuits are typically round cakes of bread that are leavened with baking powder, baking soda or sometimes yeast. It may also refer to cookies or crackers. They are mostly sweet and in history they were used by travelers as they were long-lasting foods and easy to carry (Mehta et al., 2014).

The diet of celiac patients must be completely free of any gluten, so all the products from wheat, rye, barley and oat must be replaced with corn, rice, millet equivalents and various types of starch (corn, rice and potato) or appropriate mixtures (Moore et al., (2006).Therefore, this work was design to study the effect of the present study was designed to study the effect of using some different gluten-free flour (rice flour, white corn flour, sorghum flour and their mixtures) on physical, rheological properties of the flour and quality parameters of the baked biscuits and sensory properties.

\section{MATERIALS AND METHODS Flour samples}

Wheat, rice flour,corn (white corn) and sorghum (sorghum bicolor) shortening, sugar, eggs, salt and baking powder were purchased from the local market.

\section{Methods \\ Preparation of Flour}

Wheat was tempered to $16.5 \%$ moisture and allowed to conditioning for 24 hours, then milled by laboratory mill CD1 auto Chopin, according to AACC (2000). Corn grains and sorghum grains were cleaned from foreign materials and milled using laboratory mill (3100, Perten Instruments, Sweden) to obtained whole sorghum flour. Corn and Sorghum flour was packed in polyethylene bags and stored at $\left(-18^{\circ} \mathrm{C}\right)$ until used (Abdelghafor, et al., 2013).

\section{Mixture flour}

$($ Mix 1 $)=50 \%$ Rice flour $+50 \%$ white corn flour.

(Mix

2) $=50 \%$ Rice flour $+50 \%$ sorghum flour. (Mix 3) = Rice flour + white corn flour + sorghum flour (1:1:1).

\section{Physical properties}

Hardness, starch damage, falling number, color and gluten were determined in flours according to AACC (2000).

\section{Chemical Analysis}

Wheat, rice, corn and sorghum flours were chemically analyzed for their moisture content, ash, crude protein, lipids and crud fiber contents according to the methods described in AOAC (2005). The nitrogen free extract (NFE) calculated by difference. Total carbohydrates were calculated by difference according to the following equation:

Carbohydrates $=100-($ protein $\%+$ fat $\%+$ ash \%).Caloric value was calculated according the following equation (FAO/WHO, 1974).

\section{Determination of Tannins}

Tannins determined according to Hagerman (1987) in sorghum flour. 


\section{Rheological Properties}

Rheological properties of the various glutenfree blends consist of rice flour or corn flour or sorghum flour and mixtures were determined by Alveoconsistographe and the gluten determination for wheat flour (control)according to AACC (2000).

\section{Biscuit making}

Biscuits were prepared according to the method that described by Mohamedet al., 2004)with some modifications in Table (1).Vegetable shortening was mixed with sugar until receiving a uniform mixture. Egg was then added after added vanilla and the mixture was kneaded. The dry ingredients (flour and baking powder) were thoroughly mixed in a bowl by hand for $3 \mathrm{~min}$ and mixed with liquid materials until receiving a uniform mixture. The batter was rolled and cut with a 5-mm diameter biscuit cutter. The biscuits were placed on baking trays, and baked at $180^{\circ} \mathrm{C}$ for 10 min in a baking oven. Following baking, the biscuits were cooled at ambient temperature, packed in polyethylene bags and stored at $23^{\circ} \mathrm{C}$ prior to subsequent analysis. The blend consisted of $150 \mathrm{gm}$ flour, $75 \mathrm{gm}$ sugar, 45 gm vegetable shortening, $36 \mathrm{gm}$ fresh egg, $0.5 \mathrm{gm}$ vanillin, $8.0 \mathrm{gm}$ baking powder.

\section{Physical Properties of Biscuits}

The diameter and thickness of biscuits were measured with a venire caliper. Width and length: five biscuit were placed edge to edge and their total width was measured. The average width was determined by taking the mean value (Nouma, 2003). Similarly the biscuits length was determined by placing the butt of five biscuits and taking the mean value. Thickness was measured by stacking five biscuits on top of each other and taking average thickness $(\mathrm{cm})$.Weight of biscuits was measured as average of values of flour individual biscuits with the help of digital Table 1: Formulations of biscuits weighing balance.Spread ratio was calculated by dividing the average value of width by average of thickness of biscuits by the method of Akubor, et al., (2003), using as following:

$\mathrm{SR}=\mathrm{W} / \mathrm{T}, \mathrm{W}-$ Width biscuits $(\mathrm{cm}), \mathrm{T}-$ Thickness biscuits $(\mathrm{cm})$

Volume $(\mathrm{cm} 3)=\mathrm{L}$ X WX $\mathrm{TL}=$ average length of biscuits $(\mathrm{cm}) \mathrm{W}=$ average width of biscuits $(\mathrm{cm}) \mathrm{T}=$ average thickness of biscuits ( $\mathrm{cm}$ )Density was calculated by dividing weight $(\mathrm{g})$ out volume $(\mathrm{cm} 3)$ and expressed as (g/cm3) Sneha, (2012).

\section{Color Measurement of Gluten-Free biscuits}

Color of control and gluten-free biscuits was evaluated according to Francis (1983) by using Minolta CR-400 (Minolta Camera, Co., Ltd., Osaka, Japan).

\section{Sensory Evaluation of Gluten-Free biscuits}

Control and gluten-free biscuits samples were assessed for their quality after baking by ten members' preference taste panels of wheat and four department staff. They were asked to score the internal characteristics of biscuits samples i.e. mouth feel, grain, texture, crumb color, flavor and eating quality using the respect sheet according to AACC (2000).

\section{Statisticalanalysis}

The obtained data from chemical, physical

and sensory evaluation were exposed toanalysis of variance (ANOVA). Duncan's multiple range tests at $(\mathrm{P} \leq 0.05)$ level was used to compare between means SAS (1999). 


\begin{tabular}{|l|c|c|c|c|c|c|c|}
\hline Ingredient (g) & $\begin{array}{c}\text { Wheat } \\
\text { control }\end{array}$ & $\begin{array}{c}\text { Rice } \\
\text { flour }\end{array}$ & $\begin{array}{l}\text { Maize } \\
\text { flour }\end{array}$ & $\begin{array}{l}\text { Sorghum } \\
\text { flour }\end{array}$ & Mix1 & Mix2 & Mix 3 \\
\hline Wheat flour & 150 & - & - & - & - & - & - \\
\hline Rice flour & - & 150 & - & - & 75 & 75 & 50 \\
\hline Maize flour & - & - & 150 & - & 75 & - & 50 \\
\hline Sorghum flour & - & - & - & 150 & - & 75 & 50 \\
\hline sugar & 75 & 75 & 75 & 75 & 75 & 75 & 75 \\
\hline Margarine & 45 & 45 & 45 & 45 & 45 & 45 & 45 \\
\hline Egg & 36 & 36 & 36 & 36 & 36 & 36 & 36 \\
\hline vanilla & $\mathbf{0 . 5}$ & 0.5 & 0.5 & 0.5 & 0.5 & 0.5 & 0.5 \\
\hline Baking powder & $\mathbf{8 . 0}$ & $\mathbf{8 . 0}$ & $\mathbf{8 . 0}$ & $\mathbf{8 . 0}$ & $\mathbf{8 . 0}$ & $\mathbf{8 . 0}$ & $\mathbf{8 . 0}$ \\
\hline
\end{tabular}

\section{RESULTS AND DISCUSSION}

Physical and chemical properties of flour cultivars and their mixtures

Chemical composition of different flour used in this studywas given in Table (2) the flour moisture content of different varieties ranged from (11.7 to 13.00) for all studied samples. Wheat flour had the highest value while white corn had lowest value among all samples. As regards protein content, wheat flour had the highest protein content $(12.90 \%)$ for contained gluten, followed by sorghum (10.80\%) according to Arbab (1997), while rice $(7.10 \%)$ had the lowest protein content. Additionally rice was lower oil (0.69) than other samples and white corn was higher oil content. Rice flour was lower in ash content $(0.38)$ completely with other grains. Ash content of all grains was found quite close to each other. However, highest ash content was observed in sorghum $(1.517 \%)$ these results were harmony with Neucere and Sumrell, (1980) and Mohammed (2000). The ash content of whole mill is related to the amount of mineralin the powder and therefore to nutritional value, these results were contrast with ES ,(2006) of white flour for production of bread has the following requirement: protein content not less than $10.2 \%$. Ash content not exceed than $0.9 \%$. And the falling number showed exceed than $200 \mathrm{Sec}$.

Also shown that the fiber in sorghum had significant highest value $(6.50 \%)$ while wheat flour had lowest value $(1.09 \%)$. On other hand nitrogen free extracts (NFE) \% ranged from $68.21 \%$ (sorghum) to $77.66 \%$ (rice). Total caloric values ranged between 329.54 to $357.30 \%$ for sorghum and white corn and these were agreement with the resultsthat obtained byHulse, et al.,(1980), NRC/NAS (1982), USDA/HNIS (1989), and Serna- Saldivar et al., (1990). The sorghum had the significant lowest value of tannic acid $(0.185 \%)$ and their mixtures than the maximum level (3.0\%) according to USDA, (2006).

Table 2: proximate analysis for different flour wheat, rice, white corn, sorghum and their mixtures of gluten free flour

\begin{tabular}{|l|l|}
\hline & Flours \\
\hline
\end{tabular}




\begin{tabular}{|c|c|c|c|c|c|c|c|}
\hline $\begin{array}{c}\text { Chemical } \\
\text { composition }\end{array}$ & $\begin{array}{l}\text { Wheat } \\
\text { (control) }\end{array}$ & Rice & $\begin{array}{l}\text { White } \\
\text { corn }\end{array}$ & Sorghum & Mix 1 & Mix 2 & Mix 3 \\
\hline M.C\% & $13.0^{a}$ & $12.2^{\mathrm{ab}}$ & $11.7^{b}$ & $12.0^{b}$ & $11.9^{b}$ & $12.1^{b}$ & $11.8^{b}$ \\
\hline Protein\% & $12.9^{a}$ & $7.1^{d}$ & $9.0^{c}$ & $10.80^{b}$ & $7.8^{\mathrm{cd}}$ & $8.8^{c}$ & $9.0^{c}$ \\
\hline Fat $\%$ & $1.15^{b c}$ & $0.69^{c}$ & $3.3^{a}$ & $1.50^{b c}$ & $2.00^{b}$ & $1.10^{b c}$ & $1.83^{b c}$ \\
\hline Ash\% & $0.718^{c}$ & $0.388^{d}$ & $0.775^{c}$ & $1.517^{a}$ & $0.578^{c d}$ & $1.131^{b}$ & $1.075^{b}$ \\
\hline Fiber\% & $1.09^{g}$ & $1.96^{f}$ & $2.3^{d}$ & $6.50^{a}$ & $2.13^{e}$ & $4.23^{b}$ & $3.59^{c}$ \\
\hline NFE\% & $71.14^{e}$ & $77.66^{a}$ & $72.9^{c}$ & $68.21^{f}$ & $75.59^{b}$ & $72.64^{d}$ & $72.71^{d}$ \\
\hline $\begin{array}{c}\text { Total caloric } \\
\text { values\% }\end{array}$ & $346.51^{c}$ & $345.25^{d}$ & $357.3^{a}$ & $329.54^{g}$ & $\begin{array}{c}351.56 \\
b\end{array}$ & $335.66^{f}$ & $343.33^{e}$ \\
\hline Tannic acid\% & * & $*$ & $*$ & $0.185^{a}$ & $*$ & $0.093^{a}$ & $0.062^{a}$ \\
\hline
\end{tabular}

Means with the same letter in the same row are not significantly different at $(P \leq 0.05)$.

NFE $=$ Nitrogen free extracts

$*=$ Not detected.

Physical properties of flour obtained from wheat control, rice, white corn, sorghum and their mixtures of gluten free flour.

The data in Table (3) and Fig (1)presented physical properties of flour obtained from wheat, rice, white corn, sorghum flour and their mixture of gluten free flour that the highest hardness was in white corn (80.0) while rice was the lowest (54.0), the highest starch damage was in wheat flour $(4.57 \%)$ while sorghum flour was the lowest $(0.97 \%)$.From the same Table (3) it can be concluded that the percentage of protein sediment ranged from 12 to $33 \%$, wheat flour was highest sediment ratio which had good characteristics to produce bread. Falling number which indicated enzyme activity of Alfa amylase activity. In case of falling number, white corn has highest falling number $(634.0 \mathrm{sec}$.) and lowest enzyme activity. Wheat flour $(401.0 \mathrm{sec}$.) had lower values and highest enzyme activity Means with the same letter in the same row are not significantly different.Specification of the Economic European community recommended that the falling number of flour should exceed 
than 230sec Milatovie and Mondelli, (1991).

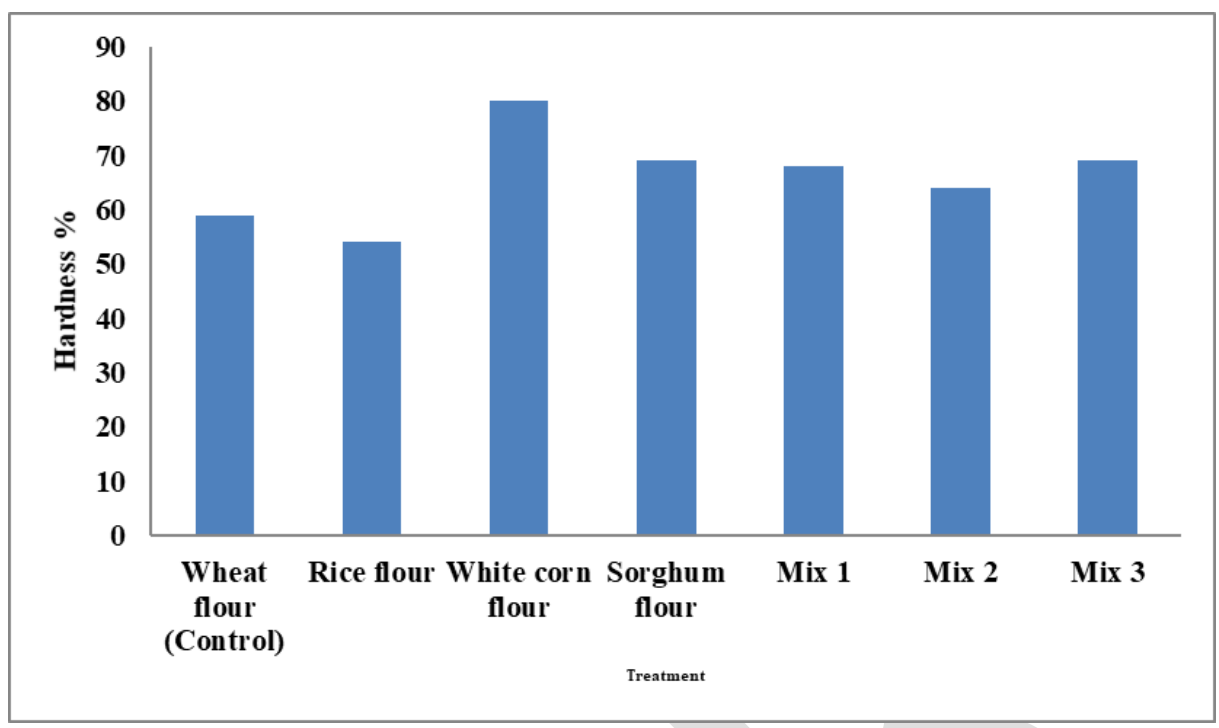

Fig (1): The hardness of different flour wheat, Rice, white corn, sorghum and mixtures of gluten free flour.

Table 3: physicochemical properties of different flour wheat, rice, white corn, sorghum and mixtures of gluten free flour.

\begin{tabular}{|c|c|c|c|c|}
\hline \multirow{2}{*}{ Samples } & \multicolumn{4}{|c|}{ Analysis } \\
\cline { 2 - 5 } & Hardness\% & $\begin{array}{c}\text { Starch } \\
\text { damage } \\
\%\end{array}$ & $\begin{array}{c}\text { Protein } \\
\text { sediment } \\
\mathrm{ml}\end{array}$ & $\begin{array}{c}\text { Falling Number } \\
\text { Sec. }\end{array}$ \\
\hline Wheat flour (Control) & $59.0^{\text {cd }}$ & $4.57^{\text {a }}$ & $33.00^{\text {a }}$ & $401.0^{\text {f }}$ \\
\hline Rice flour & $54.0^{\mathrm{d}}$ & $3.67^{\mathrm{b}}$ & $12.0^{\mathrm{f}}$ & $458.0^{\mathrm{b}}$ \\
\hline White corn flour & $80.0^{\mathrm{a}}$ & $1.29^{\mathrm{f}}$ & $18.0^{\mathrm{e}}$ & $634.0^{\mathrm{a}}$ \\
\hline Sorghum flour & $69.0^{\mathrm{b}}$ & $0.97^{\mathrm{g}}$ & $22.0^{\mathrm{b}}$ & $436.0^{\text {de }}$ \\
\hline Mix 1 & $68.0^{\mathrm{b}}$ & $3.01^{\mathrm{c}}$ & $20.0^{\mathrm{cd}}$ & $443.0^{\mathrm{cd}}$ \\
\hline Mix 2 & $64.0^{\mathrm{bc}}$ & $2.62^{\mathrm{d}}$ & $21.0^{\mathrm{bc}}$ & $447.0^{\mathrm{c}}$ \\
\hline Mix 3 & $69.0^{\mathrm{b}}$ & $1.96^{\mathrm{e}}$ & $19.0^{\mathrm{de}}$ & $434.0^{\mathrm{e}}$ \\
\hline
\end{tabular}

Means with the same letter in the same colum are not significantly different at $(P \leq 0.05)$. Rheological properties of different flour obtained from wheat flour control and different flour of rice, white corn and sorghum

rheological properties of wheat flour dough was tested by wet and dry gluten, gluten Index and Alveoconsistograph and the results indicated that the wet and the dry gluten of wheat flour wet gluten recorded 25.6, gluten index 95.9, dry gluten 8.7 but different flour and mixtures was free gluten. Alveoconsistograph studies were conducted to determine the rheological properties of different flour wheat, rice, white corn, sorghum and mixturesof gluten free flour(Table 4). Highest water absorption
$(57.0 \%)$ was observed in Wheat flour followed by rice flour $(54.40 \%)$ while flour hadthe lowest water absorption (45.7\%) mix 1 and mix2. Water absorption is considered to be an important characteristic of flour. Strong wheat flours have the ability to absorb and retain more water as compared to weak flours. Higher water absorption is required for good bread characteristics which remain soft for a longer time. Differences in alveoconsistographe characteristics among 
different wheat flour varieties may be due to variations in protein quantity and quality. All these values indicated relatively strong characteristics of wheat flour. Appositive correlation between dough rheology and hydration properties with a confidence of $99.9 \%$ was found, which suggest that the water absorption of the mixture affects the dough rheology.

\section{Color parameter of flour and biscuits produced them}

Table (5) reviewed that the rice flour had the highest value of whiteness color for seven color then wheat flour 65.3 $\%$ and $34.4 \%$ than the sorghum flour which is less in whiteness. After baking white corn biscuit was highest whiteness then wheat flour and sorghum biscuit was low whiteness. Wheat flour was highest yellowness and mix 2 was lowest in yellowness. The grains of many sorghum varieties have a dark layer in the central part containing the embryo sac, which gives a sour, bitter taste, and a dark unattractive color to flour produced from them. Yellow grains without the dark layer, however, give good quality flour, although the flour is sometimes coarse (Kordylas, 1991). Flour color, a measure of bran contamination, is measured with the Kent-Jones and Martin colorimeter. Flour color was important to the Romans, who prided themselves on making the finest, whitest flours. Even today many people still equate flour color with quality for use in food products.

If sorghum is to compete with wheat and corn products in urban areas, highly refined product will be required (Murty and Rooney, 1981). In general, white sorghum grains produced the most acceptable colored food products, but considerable variation in color of some products was acceptable. Thus it is important to measure color of grain, flour, and the food products in an efficient mannerthat your results were agreement with the previous studies(Murty and Rooney, 1981).

Table 4: Rheological properties of different flour obtained fromdifferent flour of wheat and rice, white corn, sorghum and mixturesof gluten free flour.

\begin{tabular}{|c|c|c|c|c|c|c|c|c|}
\hline \multicolumn{2}{|r|}{ Flour } & wheat & Rice & White & Sorghum & Mix 1 & Mix 2 & Mix 3 \\
\hline 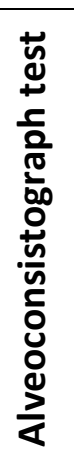 & $\begin{array}{c}\text { Water } \\
\text { absorption } \\
\%\end{array}$ & $57.0^{\mathrm{a}}$ & $54.40^{b}$ & - & - & $45.70^{c}$ & $45.70^{c}$ & $45.90^{c}$ \\
\hline
\end{tabular}

$(-)=$ Not determined

Means with the same letter in the same row are not significantly different at $(P \leq 0.05)$.

Table 5: Color parameter of flour and biscuits produced them.

\begin{tabular}{|l|l|l|}
\hline Samples & Flour & Biscuits \\
\hline
\end{tabular}




\begin{tabular}{|l|c|c|c|c|}
\hline \multirow{2}{*}{} & \multicolumn{2}{|c|}{} & & \\
\cline { 2 - 5 } & White & yellow & White & yellow \\
\hline Wheat & $34.4^{\mathrm{c}}$ & $14.6^{\mathrm{d}}$ & $33.66^{\mathrm{b}}$ & $52.02^{\mathrm{a}}$ \\
\hline Rice & $65.3^{\mathrm{a}}$ & $6.7^{\mathrm{f}}$ & $27.72^{\mathrm{e}}$ & $46.28^{\mathrm{d}}$ \\
\hline White corn & $26.0^{\mathrm{d}}$ & $16.2^{\mathrm{b}}$ & $37.80^{\mathrm{a}}$ & $51.80^{\mathrm{a}}$ \\
\hline Sorghum & $13.3^{\mathrm{e}}$ & $19.8^{\mathrm{a}}$ & $24.88^{\mathrm{f}}$ & $46.54^{\mathrm{c}}$ \\
\hline Mix 1 & $42.1^{\mathrm{b}}$ & $11.9^{\mathrm{e}}$ & $30.60^{\mathrm{c}}$ & $40.02^{\mathrm{f}}$ \\
\hline Mix 2 & $26.9^{\mathrm{d}}$ & $15.4^{\mathrm{c}}$ & $29.22^{\mathrm{d}}$ & $48.64^{\mathrm{b}}$ \\
\hline Mix 3 & $25.9^{\mathrm{d}}$ & $15.9^{\mathrm{bc}}$ & $23.46^{\mathrm{g}}$ & $40.62^{\mathrm{e}}$ \\
\hline
\end{tabular}

Means with the same letter in the same colum are not significantly different at $(P \leq 0.05)$.

Physical properties and baking quality of biscuits

Table (6) and fig (2)indicated the physical properties and baking quality of biscuits results of length, width, thickness, weight, volume, spread ratio and density of biscuits made with different flour obtained from wheat flour and different flour of rice, white corn, sorghum and mixtures of gluten free flour. The length and width was highest in wheat flour biscuit and thickness was higher in mix 1 and mix 2. Whitecorn biscuit was highest in weight and lowest in mix 2 biscuit. Fig (2) shows volume of biscuit from different flour and mixtures the highest volume was control and lowest volume with rice flour and mix 1. Excellent wheat flour gives biscuits with high spread ratio (diameter/thickness), volume, than poor flour. Fig (3)showsdensity of biscuit from different flour and mixtures gluten free flour.

Addition of sorghum flour affects the spread ratio of biscuits, than poor flour and these results were agreement with (Ibtihag, 1992), Cronin and Preis (2000).

Table (6): Physical properties of biscuits.

\begin{tabular}{|l|l|l|l|l|l|l|l|}
\hline \multirow{2}{*}{ Samples } & \multicolumn{7}{|c|}{ Physical properties } \\
\cline { 2 - 7 } & $\begin{array}{l}\text { Length } \\
(\mathrm{cm})\end{array}$ & $\begin{array}{l}\text { Width } \\
(\mathrm{cm})\end{array}$ & $\begin{array}{l}\text { Thickness } \\
(\mathrm{cm})\end{array}$ & $\begin{array}{l}\text { Weight } \\
(\mathrm{g})\end{array}$ & $\begin{array}{l}\text { Volume } \\
(\mathrm{c})\end{array}$ & $\begin{array}{l}\text { Spread } \\
\text { ratio } \\
(\mathrm{cm})\end{array}$ & $\begin{array}{l}\text { Density } \\
\left(\mathrm{g} / \mathrm{cm}^{3}\right)\end{array}$ \\
\hline $\begin{array}{l}\text { Wheat flour } \\
\text { (Control) }\end{array}$ & $9.40^{\mathrm{a}}$ & $4.30^{\mathrm{a}}$ & $0.80^{\mathrm{a}}$ & $9.02^{\mathrm{b}}$ & $32.34^{\mathrm{a}}$ & $5.38^{\mathrm{a}}$ & $0.28^{\mathrm{a}}$ \\
\hline Rice flour & $8.00^{\mathrm{b}}$ & $3.60^{\mathrm{b}}$ & $0.80^{\mathrm{a}}$ & $7.74^{\mathrm{e}}$ & $23.04^{\mathrm{f}}$ & $4.50^{\mathrm{b}}$ & $0.34^{\mathrm{a}}$ \\
\hline $\begin{array}{l}\text { White corn } \\
\text { flour }\end{array}$ & $9.20^{\mathrm{ab}}$ & $3.60^{\mathrm{b}}$ & $0.80^{\mathrm{a}}$ & $9.38^{\mathrm{a}}$ & $26.50^{\mathrm{c}}$ & $4.50^{\mathrm{b}}$ & $0.35^{\mathrm{a}}$ \\
\hline $\begin{array}{l}\text { Sorghum } \\
\text { flour }\end{array}$ & $9.00^{\mathrm{ab}}$ & $3.40^{\mathrm{bc}}$ & $0.80^{\mathrm{a}}$ & $8.60^{\mathrm{c}}$ & $24.48^{\mathrm{d}}$ & $4.25^{\mathrm{c}}$ & $0.35^{\mathrm{a}}$ \\
\hline Mix 1 & $9.00^{\mathrm{ab}}$ & $3.20^{\mathrm{c}}$ & $0.80^{\mathrm{a}}$ & $7.82^{\mathrm{de}}$ & $23.04^{\mathrm{f}}$ & $4.00^{\mathrm{d}}$ & $0.34^{\mathrm{a}}$ \\
\hline Mix 2 & $8.40^{\mathrm{ab}}$ & $3.10^{\mathrm{c}}$ & $0.90^{\mathrm{a}}$ & $6.66^{\mathrm{f}}$ & $23.44^{\mathrm{e}}$ & $3.44^{\mathrm{f}}$ & $0.28^{\mathrm{a}}$ \\
\hline Mix 3 & $9.20^{\mathrm{ab}}$ & $3.40^{\mathrm{bc}}$ & $0.90^{\mathrm{a}}$ & $7.94^{\mathrm{d}}$ & $28.15^{\mathrm{b}}$ & $3.78^{\mathrm{e}}$ & $0.28^{\mathrm{a}}$ \\
\hline
\end{tabular}

Means with the same letter in the same colum are not significantly different at $(P \leq 0.05)$. 


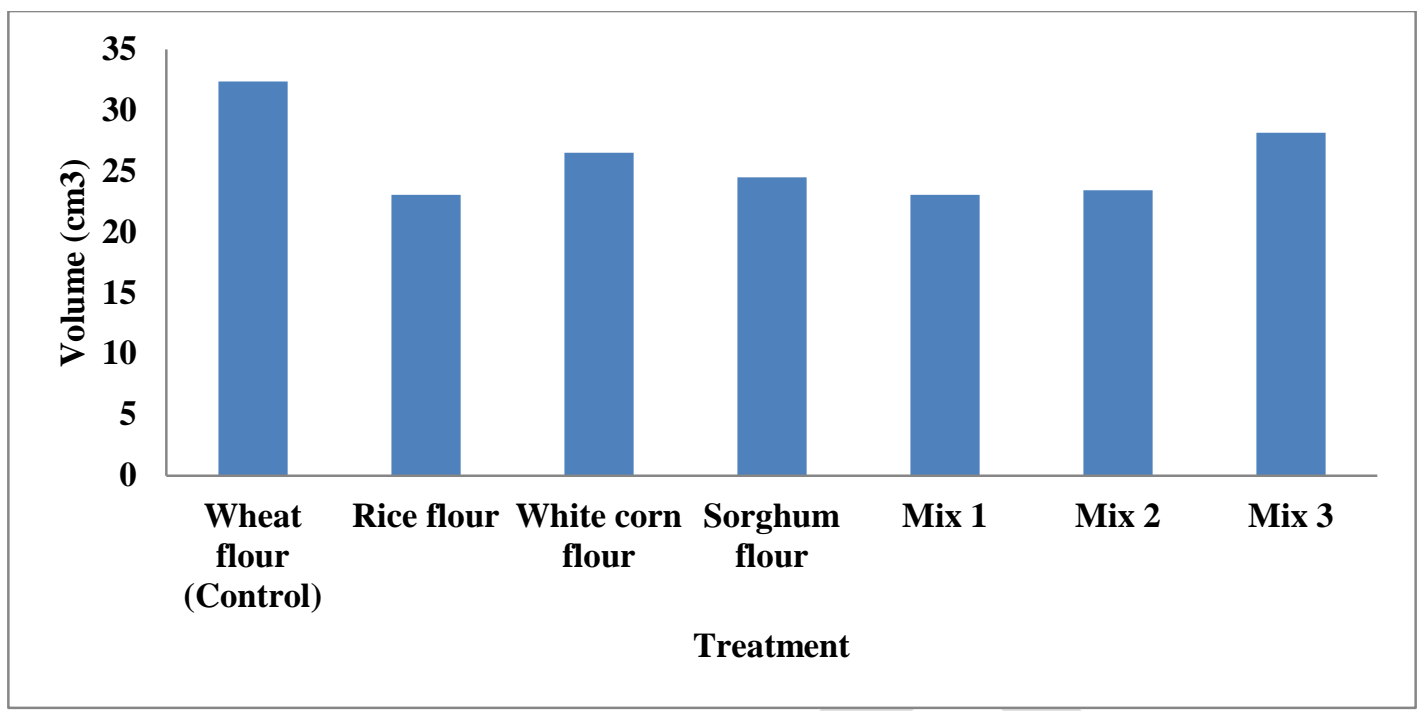

Fig (2): Volume of biscuit from different flour and mixtures of gluten free flour.

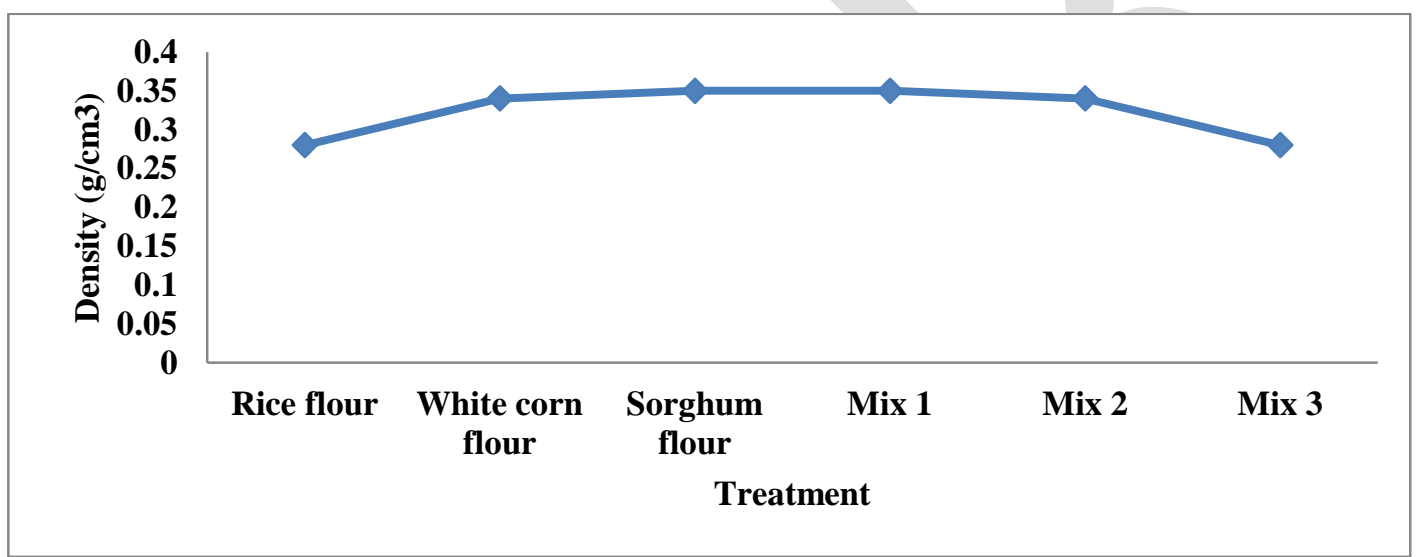

Fig (3): Density of biscuit from different flour and mixturesof gluten free flour.

Sensory evaluation of biscuits made from rice, white corn, sorghum and their mixtures of gluten free flour

Results of sensory evaluation of biscuit which made from different flour are shown in Table (7). The statistical analysis for color was significantly differences between all biscuits making from different flour which ranged from 10.66 to $18.88 \%$.

Highest value of color (18.88) was obtained by (control) wheat biscuit whereas (sorghum) got the lowest score (10.66). Lowest value of color may be due to high ash content, which affects the color of biscuit consumers prefer yellow color and not dark yellow biscuit. For texture highest mean score with control then mixtures 3 then 2 then 1 and lowest value was white corn biscuits (19.33, 18.00, 17.33, 17.00, and 11.66, respectively). Maximum taste score (18.3) was obtained by control then mix 3 while (white corn) biscuit received the minimum score (12.0).

The high odor score was mix 3 after control (17.00- 17.66) and the lowest score was white corn biscuit. Aroma score was high mix 3 after control biscuit and the lowest score was white corn biscuit. With respect to total score of biscuithighest score (87.66) for mix 3 after control (95.66) was obtained and thus regarded as more acceptable than other biscuit and mixture while lowest score (64.98) was obtained by (white corn) biscuit thus considered least acceptable. These results that obtained by Yaseen $\boldsymbol{e t} \boldsymbol{a l}$., (2010). 
Table (7): Sensory evaluation of biscuits made from rice, white corn, sorghum and their mixtures of gluten free flour

\begin{tabular}{|l|l|l|c|c|c|l|}
\hline \multirow{2}{*}{ Samples } & \multicolumn{7}{c|}{ Sensory properties } \\
\cline { 2 - 7 } & $\begin{array}{c}\text { Color } \\
\mathbf{2 0}\end{array}$ & $\begin{array}{c}\text { Texture } \\
\mathbf{2 0}\end{array}$ & $\begin{array}{c}\text { Taste } \\
\mathbf{2 0}\end{array}$ & $\begin{array}{c}\text { Odor } \\
\mathbf{2 0}\end{array}$ & $\begin{array}{c}\text { Aroma } \\
\mathbf{2 0}\end{array}$ & $\begin{array}{c}\text { Total Score } \\
\mathbf{1 0 0}\end{array}$ \\
& & & & & & \\
\hline wheat & & & & & & \\
\hline Rice & $18.88^{\mathrm{a}}$ & $19.33^{\mathrm{a}}$ & $18.80^{\mathrm{a}}$ & $19.66^{\mathrm{a}}$ & $18.99^{\mathrm{a}}$ & $95.66^{\mathrm{a}}$ \\
\hline White corn & $18.33^{\mathrm{b}}$ & $12.00^{\mathrm{e}}$ & $13.33^{\mathrm{e}}$ & $16.00^{\mathrm{c}}$ & $13.00^{\mathrm{f}}$ & $72.66^{\mathrm{e}}$ \\
\hline Sorghum & $17.66^{\mathrm{cd}}$ & $11.66^{\mathrm{e}}$ & $12.00^{\mathrm{f}}$ & $12.66^{\mathrm{f}}$ & $11.00^{\mathrm{g}}$ & $64.98^{\mathrm{g}}$ \\
\hline Mix 1 & $10.66^{\mathrm{f}}$ & $12.66^{\mathrm{d}}$ & $16.66^{\mathrm{c}}$ & $14.33^{\mathrm{e}}$ & $14.00^{\mathrm{e}}$ & $68.31^{\mathrm{f}}$ \\
\hline Mix 2 & $17.33^{\mathrm{de}}$ & $17.00^{\mathrm{c}}$ & $15.66^{\mathrm{d}}$ & $15.00^{\mathrm{d}}$ & $16.00^{\mathrm{c}}$ & $80.99^{\mathrm{d}}$ \\
\hline Mix 3 & $17.00^{\mathrm{e}}$ & $17.33^{\mathrm{c}}$ & $16.66^{\mathrm{c}}$ & $15.33^{\mathrm{d}}$ & $15.66^{\mathrm{d}}$ & $81.98^{\mathrm{c}}$ \\
\hline
\end{tabular}

Means with the same letter in the same colum are not significantly different at $(P \leq 0.05)$.

\section{CONCLUSION}

Use of gluten - free flours had considerable effects on physical, chemical and sensory properties of biscuits. That obtained the results it could be concluded that, it is feasible to produce gluten free biscuit samples from rice, white corn, sorghum flours and their mixture (1.2.3). Mix 3 was high physical and sensory characteristics nearest to biscuit samples from wheat flour (100\% gluten). From the technological, nutritional and sensory perspectives, the utilization of mix of rice and corn and sorghum are viable and recommended in the food industry to partially substitute the flour of other glutenfree cereals and diversifying the bakery market. The prepared biscuit samples could be used for celiac patients who cannot consume diets containing gluten.

\section{REFERENCES}

AACC, (2000).American association of cereal chemists, Approved method of the AACC $10^{\text {th }}$ ed., vol. 1, AACC, St Paul, MN.

Abdelghafor, R.F., Mustafa, A.I., Ibrahim, A.M.H., Chen, Y.R. and Krishnan, P.G. (2013).Effects of
Sorghum Flour Addition on Chemical and Rheological Properties of Hard White Winter Wheat. Advance Journal of Food Science and Technology , 5, 14071412.

AOAC, (2005).Association of Official AnalyticalChemists.Official

Methods of Analysis. $18^{\text {th }}$ Ed. Published by A.O.A.C. W.Horwitz. North Frederick, U.S.A.

Akubor,P.I. and Ukwuru , M.U. (2003). Functional properties and biscuit making potential of soybean and cassava flour blends, Plant Foods for human Nutrition 58:1-12.

Amin, R.; N. Muphyand J. Edge, (2002). Study of effect of a gluten free diet on glycemic control and weight gain in subjects with type 1 diabetes and celiac disease. Diabetes Care, 25, 1117-1122.

Arbab, M. E. and A. H. El Tinay, (1997).Effect of Cooking and Treatment with Sodium Bisulphiteand Ascorbic Acid on In vitro Protein Digestibility of Two Sorghum Cultivars.Food Chem., 29, 339-344. 
Case, S. (2005). The gluten-free diet: How to provide effective education and resources. Gastroenterology 128:128_134.

Ciacci, C., L. Maiuri, ,N. Caporaso, , C. Buccia, , L. Del Giudice,, D.

R.Massardo, , P. Pontieri, N. Di

Fonzoe, , S. R. Bean, , B.

Ioergerfand M. Londei

(2007).Celiac disease: in vitro and in vivo safety and palatability of wheat-free sorghum food products. Clinical Nutr.26(6):799-805.

Cronin, K. and Preis, C. (2000). A statistical analysis of biscuit physical properties as affected by baking.J. Food Engineering.46, 217-225.

ES, (2006). Egyptian Standard of white flour for production of bread. Egyptian Organization for Standardization and Quality Control, No. 1419.Arab Republic of Egypt.

FAO/WHO, (1974).Energy and protein requirement.FAO nutrition meeting report series No.52 FAO. Rome.

Francis, F.J. (1983). Colorimetric of Foods. In: Peleg, M. and Bagly, E.B., Eds., Physical Properties of Foods , The AVI Publishing Company Inc., Westport, CT, 105123.

Gallagher, E., T.R. Gormley and E. K. Arendt (2003 a). Crust and crumb characteristics of gluten-free breads. J. Food Eng. 56:153- 161.

Gallagher, E., A. Kunkel, T.R. Gormley andE. K. Arendt (2003 b).The effect of dairy and rice powder addition on loaf and crumb characteristic, and shelflife (intermediate and long-term) of gluten-free breads stored in modified atmosphere. Eur. Food Res. Technol. 218:44- 48.

Gallagher, E., T. R. Gormley andE. K. Arendt,(2004). Recent advances in the formulation of gluten-free cereal based products. Trends Food Sci. Technol. 15:143_152.

Gambus, H., A.Nowotna, R. Ziobro, D. Gumul and M.Sikora,(2001). The Effect of use of guar gum with pectin mixture in gluten-free bread. EJPAU, Food Sci. Technol. 4(2). Available online at: http://www.ejpau.media. $\mathrm{pl} /$ volume4/issue2/food/abs09.html. (accessed 1 September 2001).

Hagerman, A.E. (1987).Radial Diffusion Method for Determining Tannins in Plant Extracts. Journal of Chemistry Ecology, 13, 437-449.

Hamer, R.J. (2005). Coeliac disease: background and biochemical aspects. Biotechnology Advances, 23, 401-408.

Hill, I.D., M.H.Dirks, G. S. Liptak, R.B.Colletti, A. Fasano andS. Guandalini, (2005). Guideline for the Diagnosis and Treatment of Celiac Disease in Children: Recommendations of the North American Society for Pediatric Gastroenterology, Hepatology and Nutrition. Journal of Pediatric Gastroenterology Nutrition, 40, 119.

He, H. and R. C. Hoseney, (1990).

Changes in bread firmness and moisture during long-term storage. Cereal Chem 67:603_605.

Helm, R.M. and A.W. Burks, (1996).Hypoallergenicity of Rice Protein. Cereal Foods World, 41, 839-843.

Hulse, J. H.; E. M. Latingand O.E. Pearsoin, (1980).Sorghum and millet. Their composition and nutritive value. International Development Research Center, Ottawa, Canada .

Ibtihag, A. A. Mahmoud, (1992). BISCUITS FROM COMPOSITE FLOUR OF WHEATAND SORGHUM.University of Gazira.H.Sc. Sudan. 
Kasarda, D.D. (2001).Grains in relation to celiac disease. Cereal Foods World, 46, 209-210.

Kiskini,A., K. Argiri, M.

Kalogeropoulos, M. Komaitis, A. Kostaropoulos, I. Mandala and

M. Kapsokefalou, (2007) .

Sensory characteristics and iron dialyzability of gluten-free bread fortified with iron. Food Chem. 102:309_316.

Kordylas, J.M. (1991).Processing and preservation of tropical and subtropical foods. Macmillan Education Ltd. Hounmills, Basing Stoke. British.

Korus, J.,K. Grzelak, B. Achremowicz and R. Sabat, (2006). Influence of prebiotic additions on the quality of gluten-free bread and on the content of inulin and fructooligosaccharides. Food Sci. TechnolInt 12:489_495.

Laurin, P., M.Wolving\& K. FalthMagnusson, (2002). Even small amounts of gluten cause relapse in children with celiac disease. Journal of Pediatric Gastroenterol Nutrition, 34, 26-30.

Lazaridou,A. ,D .Duta, M Papageorgiou, $\mathrm{N}$.Belc, C. G.Biliaderis, (2007). Effects of hydrokoloids on dough rheology and bread quality parameters in gluten-free formulations. J. Food Eng. 79:1033_1047.

Lopez A.C.B., A.J.G. Pereira and R.G. Junqueira, (2004). Flour mixture of rice flour, corn and cassava starch in the production of gluten-free white bread. Brazilian Arch. Biol. Technol., 47, 63-70.

Masoodi, L.andV.A.K.Bashir, (2012). Fortification of biscuit with flaxseed: Biscuit production and Quality Evaluation, Journal of Environmental Science, Toxicology and Food Technology, 1:6-9.

Milatovie, L. and G.Mondelli, (1991).Pasta Technology
Today.Ed. by ChiriottiPoinerolo (To) - Italy.

Matos, M.E. and C.M. Rosell, (2011).Chemical Composition and Starch Digestibility of Different Gluten-Free Breads. Plant Foods for Human Nutrition, 66, 224-230.

Mehta, K.R., S.M. Shivkarand A. Shekhar, (2014).A Study of Multigrain Gluten Free Groundnut and Edible Gum Biscuits.International Journal of Food and Nutritional Sciences, 3, 201-206.

Mohammed, A.O. (2000). The role of sorghum flour starches (amylase, amylopectin) in composite bread quality.University of Khartoum. M.Sc. Sudan.

Mohamed H.A.; M.M. Elsoukkary; M.M. Doweidar, A.A. Atia, (2004).Preparation,

characterizations and health effects of functional biscuits containing isoflavones.Minufiya J. Agric. Res., 2(29): 425-434.

Moore, M.M., M.Heinbockel, , P. Dockery, , H.E. Ulmer and E.K. Arendt, (2006).Network Formation in Gluten-Free Bread with Application of Transglutaminase.Cereal Chemistry, 83, 28-36.

Murty, D.S. and L.W. Rooney, (1981).Color of sorghum food products. In: Processing of the International Symposium of Sorghum Grain Quality. ICRISAT, Centre Patancherue, India, p: 323333.

Neucere, N.J. and G. Sumrell, (1980).Chemical composition of different varieties of grain sorghum.J. Agric. Food Chem. 28: 19-21.

Nouma,R. (2003).Sensory and physical evaluation of biscuits supplemented with soy flour, Pak J. Food, 13 (12): 45-48. 
NRC/NAC, (1982). United States-Candian tables of feed composition, third revision. National Academy Press, Washington, D. C.

Phimolsiripol, Y., A. Mukprasirt, and R. Schoenlechner, (2012). Quality Improvement of Rice Based Gluten Free Bread Using Different Dietary Fiber Fractions of Rice Bran.Journal of Cereal Science, 56, 389-395.

Polimac, M., \& D. K. Komlenic, (2015).Acorn flour, naturally gluten-free.In Proceedings of the 8th International Congress "FlourBread"Opatija, Croatia, 10th Croatian Congress of Cereal Technologists, 177-181.

Polimac, M., D. K. Komlenic\& J. Lukinac, (2015). Possibilities of using acorn flour in products based on flour. In Proceedings of the 8thInternational Congress "FlourBread"Opatija, Croatia, 10th CroatianCongress of Cereal Technologists, 33-48.

Rai, S. (2011).Quality characteristics of gluten free cookies prepared from different flour combinations, $J$. Food Sci. Technol.

Rasmussen, P. H. and A.Hansen (2001). Staling of wheat bread stored in modified atmosphere. LebensmWiss Technol. 34:487_491.

Rewers,M. (2005). Epidemiology of celiac disease: What are the prevalence, incidence, and progression of celiac disease? Gastroenterology 128(4, Suppl. 1):47_51.

SAS, (1999). SAS / Stat. User's Guide: statistics, system for windows, version 4.10 (releasa 6.12 TS level
0020), SAS Inst., Inc. Cary, North Carolina, USA.

Serna- Saldivar, S.O; M.H. Gomez \&L.W. Rooney, (1990). The technology, chemistry and nutritional value of alkaline cooked corn products. In: Advances in Cereal Science and Technology, Vol. 10 Y. Pomeranz, Ed. American Association of Cereal Chem., St. Paul, MN. USA.

Sneha, S.R, (2012). Preparation and Quality Evaluation of Flour and Biscuit from Sweet Potato, J. Food Process Technol 3:192. P. 1-5.

Thompson L. (2000). Folate, iron and dietary fibre contents of the glutenfree diet. J. Am. Diet Assoc. 1000:1389_1396.

USDA, (2006). United Stats Department of Agriculture. Grain Inspection Handbook II Grain Inspection, Packers and Stockyards

USDA/HNIS,(1989). Composition of Foods: Cereal grains and pasta. U. S. Dep. Agric. Handb. 8-20 U.S. Govt. Printing Office, Washington, D.C. Administration, Federal Grain Inspection Service.

Yaseen A.A., A.A. Shouk and M.T. Ramadan (2010). Corn-wheat pan bread quality as affected by hydrocolloids. J. Amer. Sci., 6, 684690.

Yildiz Ö. and B. Bulut (2017).Optimization of gluten-free tulumba dessert formulation including corn flour: response surface methodologyapproach. Pol. J. Food Nutr. Sci., 67, 25-31. 